\title{
Kewajiban Keterbukaan dan Prinsip Rahasia Bank di Pasar Modal
}

\author{
Nazarudin
}

\begin{abstract}
As one of the alternative for supporting the stronghold and adding the bank capital, it can be taken through public bargaining at the stock exchange. In the public bargaining, every bank must pay attention for two basic principles, namely transparency and secrecy principles. But the instrument of the act, like number 23, 1964, The act of number 14, 1967, and the act of Number 7, 1992 as well as the act of number 10,1998 are unadequate of protection certainty in supporting activities.
\end{abstract}

\section{Pendahuluan}

Modal sangat dibutuhkan untuk menjaga kelangsungan hidup perusahaan maupun !ntuk pengambangan usaha suatu perusahaan. Pertanyaannya adalah darimanakah perusahaan memperoleh modal, terutama dalam bentuk uang (fresh money), untuk memenuhi kebutuhan tersebut? Altematif bagi perusahaan untuk mengatasi kebutuhan akan modal antara lain dengan mencari pihak lain untuk berpartisipasi sebagai pemilik perusahaan dengan cara menanamkan modal. Apabila cara ini yang dilakukan, berarti perusahaan harus menjual sebagiàn dari modal yang berupa kepemilikan (equity) atas perusahaan atau biasa disebut dengan saham perusahaan kepada masyarakat luas. Kegiatan perusahaan mencari modal melalui penjualan saham kepada masyarakat luas dikenal dengan istilah penawaran umum.'

Jika perusahaan yang akan menawarkan sebagian sahamnya kepada masyarakat luas mempunyai usaha di bidang Perbankan, Pasal 26 ayat (1) Undang-undang No. 10 Tahun 1998 tentang Perubahan atas Undangundang No. 7 Tahun 1992 tentang Perbankan² menyatakan bahwa bank umum dapat melakukan emisi saham melalui bursa efek di Indonesia.

Setiap perusahaan yang bermaksud menawarkan efeknya di pasar modal harus

' Pasal 1 angka 15 Undang-undang No. 8 Tahun 1995 tentang Pasar Modal menyebutkan penawaran umum adalah kegiatan penawaran Efek yang dilakukan oleh Emilen untuk menjual Efek kepada masyarakat berdasarkan tata cara yang dialur dalam Undang-undang ini dan peraluran pelaksanaannya. 
memberikan informasi atau fakta penting dan relevan mengenai peristiwa, kejadian, atau fakta yang dapat mempengaruhi harga efek di bursa dan atau keputusan investor, calon investor atau pihak lain yang berkepentingan atas informasi atau fakta tersebut. Keterbukaan ini disebut dengan prinsip keterbukaan (disclosure principle).

Bagi bank umum yang akan melakukan emisi saham, kewajiban disclosure ini seringkali tarik menarik dengan prinsip kerahasiaan bank. Di situ sisi bank sebagai lembaga keuangan berdasarkan kepercayaan wajib menjaga rahasia bank agar nasabah atau masyarakat tetap percaya, sedangkan di sisi lain sebagai bank umum yang menjual sahamnya di lantai bursa mempunyai kewajiban untuk mentaati prinsip keterbukaan agar investor. memperoleh perlindungan hukum.

\section{Pengaturan Rahasia Bank di Indonesia}

Yunus Hesein memberikan pengertian rahasia bank, yang dalam Bahasa Inggris disebut dengarı istilah bank secrecy atau di' Amerika Serikat disebut financial privacy, dalam arti yang luas dan dalam arti yang sempit. ${ }^{3}$ Rahasia bank dalam arti luas adalah segala sesuatu yang berhubungan dengan keterangan mengenai nasabah bank dan keterangan mengenai kondisi keuangan dan usaha bank. ${ }^{4}$ Sedangkan pengertian rahasia bank dalam arti sempit dapat ditemukan dalam Pasal 1 angka 28 Undang-undang Perbankan yang menyebutkan rahasia bank adalah segala sesuatu yang berhubungan dengan keterangan mengenai nasabah penyimpanan dan simpanannya.

Apabila ditelusuri batasan pengertian rahasia bank di Indonesia, maka akan terlihat ketidakjelasàn pengaturannya, baik dalar: Undang-undang No. 23 Tahun 1964, Undangundang No. 14 Tahun 1967, Undang-undang No. 7 Tahun 1992, maupun dalam Undangundang No. 10 Tahun 1998. Ketidakjelasan: pada peraturan perundang-undangan sebelum 1998 bersumber dari ruang lingkup rahasia bank yang terlaiu luas, meliputi "keadaan keuangan nasabah" dan "hal-hal lain dari

${ }^{2}$ Selanjutnya disebut Undang-undang Perbankan.

3 Yunus Husein, Rahasia Bank Privasi Versus Kepentingan Umum (Jakarta: Program Pascasarjana Fakultas Hukum Universitas Indonesia), him. 48.

4 Nasabah berdasarkan Pasal 1 angka 16 Undang-undang Perbankkan diartikan sebagai pihak yang menggunakan jasa bank. Kondisi keuangan bank adalah segala sesuatu yang berhubungan dengan keadaan keuangan bank, baik pada sisi aktiva, pasiva maupun administratif. Berdasarkan Pasal 2 PBI No. 3/22/PBI/2001 tentang Transparansi Kondisi Keuangan, bank wajib menyusun dan menyajikan laporan keuangan yang lerdiri dari Laporan Tahunan, Laporan Keuangan Publikasi Triwulanan, laporan Publikasi Keuangan Bulanan dan Laporan Publikasi Keuangan Konsolidasi. Usaha bank sebagaimana dimaksud dalam Pasal 6 dan 7 Undangundang Perbankan adalah usaha menghimpun dana dari masyarakat, menyalurkan dana kepada masyarakat, memberikan jasa di bidang perbankan dan lalu lintas pembayaran, menerbitkan, menjamin dan melakukan jual beli surat berharga dan melakukạn penyertaan yang diperbolehkan menurut ketentuan perundang-undangan yang berlaku.

${ }^{5}$ Yunus Husein. op.cit. hlm. 4-5 
nasabah bank yang harus dirahasiakan menurut kelaziman dalam dunia Perbankan." ${ }^{.6}$

Berlakunya Undang-undang No. 10 Tahun 1998 tentang Perubahan atas Undang-undang No. 7 Tahun 1992 tentang Perbankan mengurangi ketidakjelasan rahasia bank, dengan menyebutkan rahasia bank adalah segala sesuatu yang berhubungan dengan keterangan mengenai penyimpanan dan simpanannya. Namun, dalam Undang-undang' No. 10 Tahun 1998 apa yang dimaksud dengan "segala sesuatu yang berhubungan" dan "keterangan mengenai nasabah penyimpanan dan simpanannya" tidak diatur secara jelas. Definisi tersebut meliputi unsur subjektif yang menyangkut diri nasabah penyimpan, dan unsur objektif yaitu simpanan nasabah.

Terhadap pengaturan demikian renimbulkan beberapa pertanyaan, antara lain: Apakah segala sesuatu mengenai diri penyimpan dana dan simpanan harus dirahasiakan oleh bank, misalnya nama nasabah, :iamat, dan nomor rekening? Siapakah nasabah penyimpan dana yang harus dirahasiakan? Apakah nasabah penyimpanan dana perorangan atau badan hukum? Apakah rahasia bank meliputi nasabah bank yang masih aktif atau meliputi pula mantan nasabah bank? Apakah nasabah bukan penyimpan dana (debitor) tidak wajib dirahasiakan?

Muhammad Djumhana berpendapat bahwa pengertian rahasia bank bersifat nisbi dan mutlak. Rahasia bank bersifat nisbi artinya bank diperbolehkan membuka rahasia nasabahnya apabila untuk suatu kepentingan mendesak, misalnya demi kepentingan negara, sedangkan rahasia bank bersifat mutlak artinya bank berkewajiban menyimpan rahasia nasabah yang diketahui oleh bank karena kegiatan usahanya dalam keadaan apapun, biasa atau dalam keadaan luar biasa.

Pendirian aliran nisbi akan bersedia melepaskan kewajibannya untuk menyimpan rahasia demi kepentingan masyarakat, yang dalam praktiknya berpijak pada asas proporsional dan asas subsider. Asas proporsional menghendaki pertimbangan kepentingan mana yang lebih berat, yaitu tidak membuka rahasia yang berarti menyimpan rahasia hanya memenuhi kepentingan terbatas yaitu kalangan perbankan, atau membuka rahasia demi kepentingan yang lebih besar yaitu kepentingan negara. Pertimbangan dalam memilih tersebut dihubungkan dengan pemilihan kepentingan.?

Undang-undang Perbankan Indonesia menganut pengertian rahasia bank yang bersifat relatif, ${ }^{8}$ artinya rahasia bank

\footnotetext{
${ }^{6}$ Lihat Pasal 1 angka 16 Undang-undang No. 7 Tahun 1992 tentang Perbankan yang menyatakan rahasia bank adalah segala sesuatu yang berhubungan dengan keuangan dan hal-hal lain dari nasabah bank yang menurut kelaziman dunia perbankan wajib dirahasiakan. Penjelasan Pasal 41 ayat (1) Undang-undang No. 7 Tahun 1992 tentang Perbankan memaparkan kelaziman yang wajb dirahasiakan oleh bank adalah seluruh data dan informasi mengenai segala sesuatu yang berhubungan dengan keuangan dan hal-hal lain dari orang dan badan yang diketahui oleh bank karena kegiatan usahanya.

${ }^{7}$ Muhammad Djumhana, Hukum Perbankan dilndonesia(Bandung: Citra Aditya Bakti. 1996), hlm. 116-117.

${ }^{8}$ Ibid., hlm. 116. Lihat pula Muhammad Djumhana, Rahasia Bank (Ketentuan dan Penerapan di Indonesia) (Bandung: Citra Auitya Bakti, 1996), hlm. 111.
} 
memungkinkan untuk dibuka dengan alasan kepentingan umum. ${ }^{9}$ Kewajiban bank untuk merahasiakan keterangan mengenai Nasabah penyimpan dan simpanannya sebagaimana diatur dalam Pasal 40 Undang-undang Perbankan, namun berdasarkan Pasal 4144A Undang-undang Perbankan dapat diterobos atas dasar kepentingan umum. Ketentuan dalam pasal-pasal tersebut mengatur kepentingan umum yang dapat dijadikan alasan untuk membuka ketentuan rahasia bank adalah: pertama, kepentingan perpajakan. Kedua, penagihan piutang bank terutama piutang bank milik negara. Ketiga, kepentingan peradilan perkara pidana, Keempat, dalam hal sengketa perdata antara bank dan nasabah di pengadilan. Kelima, informasi antar bank. Keenam, kepentingan ahli waris. Ketujuh, adanya persetujuan atau kuasa tertulis dari nasabah.

Pihak-pihak yang berkewajiban menjaga rahasia bank berdasarkan Pasal 47 ayat (2) Undang-undang Perbankan adalah anggota dewan komisaris, direksi bank, pegawai bank, dan pihak terafiliasi. Pihak terafiliasi berdasarkan Pasal 1 angka 22 Undangundang Perbankan meliputi: pertama, anggota dewan komisaris, pengawas, direksi atau kuasanya, pejabat atau karyawan bank. Kedua, anggota pengurus, pengawas atau kuasanya, pejabat atau karyawan bank, khususnya bagi bank yang berbentuk hukum koperasi sesuai dengan peraturan perundang-undangan yang berlaku. Ketiga, Pihak yang memberikan jasanya kepada bank, antara lain akuntan publik, penilai, konsultan hukum dan konsultan lainnya. Keempat, pihak yang menurut penilaian Bank Indonesia turut mempengaruhi pengelolaan bank, antara lain keluarga para pemegang saham, komisaris, direksi, pengurus. Sedangkan yang dimaksud pegawai bank berdasarkan Pasal 48 ayat (10) Undang-undang Perbankan adalah pejabat bank yang diberi kewenangan dan tanggung jawab untuk melaksanakan tugas operasional bank dan karyawan yang mempunyai akses terhadap informasi mengenai keadaan bank.

\section{Prinsip Keterbukaan di Pasar Modal}

Pasal 1 angka 25 Undang-undang Pasar Modal ménentukan bahwa prinsip keterbukaan (disclosure principle) adalah pedoman umum yang mensyaratkan emiten, perusahan publik, dan pihak lain yang tunduk pada undangundang ini untuk menginformasikan kepada masyarakat dalam waktu yang tepat seluruh informasi material mengenai usahanya atau efeknya yang dapat berpengaruh terhadap keputusan pemodal terhadap efek dimaksud dan atau harga dari efek tersebut.

Bismar Nasution berpendapat bahwa prinsip keterbukaan merupakan jiwa pasar modal. Keterbukaan tentang fakta material sebagai jiwa pasar modal didasarkan pada keberadaan prinsip keterbukaan yang memungkinkan tersedianya bahan pertimbangan bagi investor untuk secara rasional dapat mengambil keputusan melakukan pembelian atau penjualan saham. $^{10}$

\footnotetext{
${ }^{9}$ Yunus Husein, op.cit. hIm. 7 .

${ }^{10}$ Bismar Nasution, Keterbukaan dalam Pasar Modal (Jakarta: Fakultas Hukum Program Pascasarjana Universitas Indonesia, 2001), hIm. 1
} 
Fungsi keterbukaan di pasar modal adalah:" pertama, memelihara kepercayaan publik terhadap pasar. Makin jelas informasi perusahaan, maka keinginan investor untuk melakukan. investasi semakin tinggi, sebaliknya ketiadaan, kekurangan atau ketertutupan informasi dapat menimbulkan ketidakpastian bagi investor sehingga menimbulkan ketidakpercayaan investor dalam melakukan investasi melalui pasar modal. Kedua, prinsip keterbukaan berfungsi menciptakan mekanisme pasar yang efisien. Pasar dapat dikatakan efisien jika harga saham sepenuhnya merupakan refleksi dari seluruh informasi yang tersedia. Tanpa informasi, masyarakat tidak dapat mengevaluasi produkproduk lembaga keuangan tersebut, di sisi lain jika emiten tidak menyediakan informasi secara luas dan akurat maka ia akan kehilangan kesempatan menjual sahamnya. Ketiga; prinsip keterbukaan penting untuk mencegah penipuan (fraud).

Pertanyaannya adalah apakah yang harus dibuka (disclosed) di pasar modal? Fakta atau informasi mengenai usaha atau efek perusahaan yang dapat berpengaruh terhadap keputusan permodalan terhadap efek dimaksud dan atau harga dari efek tersebut. Pasal 1 anğka 7 Undang-undang Pasar Modal menyatakan:

"Informasi atau fakta material adalah informasi atau fakta penting dan relevan mengenai peristiwa, kejadian, atau fakta yang dapat mempengaruhi harga Efek pada Bursa Efek dan atau keputusan pemodal, calon pemodal, atau pihak lain yang berkepentingan atas informasi atau fakta tersebut."

Keputusan Ketua Badan Pengawas Pasar Modal No. Kep-86/PM/1996 dan Peraturan No. X.K1 memaparkan bahwa informasi atau fakta material yang diperkirakan dapat mempengaruhi efek atau keputusan pemodal, antara lain: Pertama, penggabungan usaha, pembelian saham, peleburan usaha, atau pembentukan usaha patungan. Kedua, pemecahan saham atau pembagian deviden saham. Ketiga, pendapatan dari deviden yang luar biasa sifatnya. Keempat, perolehan atau kehilangan kontrak penting. Kelima, produk atau penemuan baru yang berarti. Keenam, perubahan dalam pengendalian atau perubahan penting dalam manajemen. Ketujuh, pengumuman pembelian kembali atau pembayaran efek yang bersifat utang. Kedelapan, penjualan tambahan efek kepada masyarakat atau secara terbatas yang material jumlahnya. Kesembilan, pembelian atau kerugian penjualan aktiva yang material. Kesepuluh, perselisihan tenaga kerja yang relatif penting, Kesebelas, tuntutan hukum yang penting terhadap perusahaan dan atau direktur dan komisaris perusahan. Keduabelas, penjualan tawaran untuk pembelian efek perusahaan lain. Ketigabelas, pergantian akuntan yang mengaudit perusahaan. Keempatbelas, pergantian wali amanat. Kelimabelas, perubahan tahun fiskal perusahaan.

Pelaksanaan prinsip keterbukaan di pasar modai dapat dikategorikan dalam tiga fase: Pertama, sebelum pernyataan pendaftaran dinyatakan efektif ( $p r a$ listing). Kedua, pada perdagangan saham di pasar perdana. Ketiga,

\section{" Ibid., hlm. 9-11}


pada perdagangan saham di pasar sekunder.

Pernyataan pendaftaran (registration statement) yang wajib diserahkan kepada badan Pengawas Pasar Modal terdiri dari prospektus awal (preliminary prospectus) dan dokumendokumen pendukung. Prospektus adalah penawaran tertulis resmi untuk menjual sekuritas yang mencantumkan rencana dari suatu usaha bisnis yang diusulkan, atau fakta-fakta yang menyangkut usaha yang sudah ada dan perlu diketahui oleh seorang investor agar dapat membuka keputusan dengan pengetahuan yang cukup. Prospektus diterbitkan pula untuk dana bersama yang menjelaskan sejarah, latar belakang para manajer, tujuan penggunaan dana, laporan keuangan, dan data penting lainnya. Prospektus berisikan informasi keuangan dan penjelasan sejarah bisnis perusahaan, operasi, perkara hukum (apabila ada), dan rencana perusahaan, termasuk penggunaan hasil penjualan dari emisi saham. ${ }^{12}$

Penjelasan Pasal 78 ayat (3) Undangundang Pasar Modal menyebutkan bahwa suatu prospektus sekurang-kurangnya memuat: Pertama, uraian tentang penawaran umum. Kedua, tujuan dan penggunaan dana penawaran umum. Ketiga, analisis dan pembahasan mengenai kegiatan dan keuangan. Keempat, resiko usaha. Kelima, data keuangan. Keenam, keterangan dari segi hukum. Ketujuh, informasi mengenai pemesanan pemebelian efek. Ketujuh, keterangan tentang Anggaran Dasar. . .

Pelaksanaan prinsip keterbukaan pada perdagangan saham di pasar perdana terputus dalam penyampaian informasi penawaran saham melalui prospektus. ${ }^{13}$ Suatu prospektus yang dibuat harus memperhatikan ketentuan dalam Pasal 81 ayat (1) Undang-undang Pasar Modal yaitu harus memuat keterangan yang benar tentang fakta materiil. Fungsi prospektus sangat vital bagi setiap investor karená prospektus memberikan pengetahuan yang cukup dan dapat digunakan sebagai bahan pertimbangan dalam membuat keputusan untuk membeli suatu saham, maka bentuk atau isi dan saat penyampaian prospektus kepada calon investor memerlukan pengetahuan yang cukup sehingga dapat bermanfaat sebagai salah satu cara untuk melindungi investor dại penjualan yang curang (fraudulent sales). ${ }^{14}$

Di Amerika Serikat, selain fakta materiil yang wajib disampaikan, perusahaan diwajibkan juga untuk menyampaikan informasi perusahaan yang berkenaan dengan manajemen, termasuk mengenai informasi proyek internalnya (internal projection). Adapun ukuran dari tanggung jawab suatu "forward looking statemenf' diletakkan pada pernyataan yang dibuat berdasarkan itikad baik dan mempunyai suatu dasar yang layak. Pernyataan ini harus memperhatikan empat hal sebagai berikut. Pertama, pernyataan yang berisi proyeksi keuntungan, pendapatan perusahaan, biaya modal, deviden, struktur

${ }^{12}$ Bismar Nasution, op.cil., hlm. 104. Sebagaimana mengutip John Downes dan Jordan Ellion Goodman, Dictionary of Finance and Invesment Term (penerjemah Soesanto Budhidarmo). (Jakarta: Gramedia, 1396), hlm. 438.

${ }^{13}$ Bismar Nasution. op.cit., hlm. 151-152.

" Ibid, him. 153. 
permodalan dan hak-hak keuangan lainnya. Kedua, pernyataan tentang rencana manajemen dan tujuan operasi di masa depan. Ketiga, pernyataan tentang kinerja masa depan yang berisi pembahasan manajemen dan analisis keuangan dan hasilhasil operasi. Keempat, yang harus dinyatakan adalah pernyataan keterbukaan tentang asumsi-asumsi yang berdasarkan dan berhubungan dengan pernyataan-pernyataan pertama, kedua dan ketiga. ${ }^{15}$

\section{Prinsip Keterbukaan pada Perdagangan Saham di Pasar Sekunder}

Linsting, merupakan tahap akhir dari rangkaian proses go-public. Setelah listing, emiten masuk ke pasar sekunder dan harga saham yang diperdagangkan ditentukan oleh mekanisme pasar. Pada pasar sekunder prinsip keterbukaan dilaksanakan melalui penyampaian laporan keuangan secara berkala, laporan mengenai fakta materiil yang baru, larangan insider trading, dan larangan manipulasi pasar.

Laporan keuangan secara berkala, dilakukan kepada Bapepam dan mengumumkannya kepada investor, sebagaimana diatur dalam Pasal 28 ayat (1) butir a Undang-undang Pasar Modal. ${ }^{\text {t6 }}$ :Berdasarkan laporan-laporan tersebut dapat disusun evaluasi cash flows yang akan datang dan selanjutnya membuat estimasi nilai saham. Keterlambatan atas penyampaian laporan keuangan berkala merupakan pelanggaran prinsip keterbukaan.
Pelanggaran tersebut diancam dengan sanksi administratif berupa denda sebesar Rp. $1.000 .000,00$ (satu juta rupiah) atas setiap hari keterlambatan penyampaian laporan dengan ketentuan jumlah keseluruhan denda paling banyak Rp. 500.000.000,00 - (lima ratus juta rupiah) berdasarkan Pasal 63 butire Peraturan Pemerintah No. 45 Tahun 1995 tentang Penyelenggaraan Kegiatan di Bidang Pasar Modal.

Keterbukaan mengenai adanya Fakta Materil Baru, suatu fakta materiil baru harus segera dilaporkan paling lambat 2 (dua) hari kerja, untuk segera diumumkan kepada publik. Fakta materiil yang harus disampaikan kepada publik apabila fakta materiil tersebut dapat mempengaruhi harga saham, seperti kebakaran, pemogokan, perusahaan ditutup, tender offer, merger atau peleburan dan akuisi.

Insider trading bertentangan dengan prinsip keterbukaan, karena yang bersangkutan memberi atau menjual saham berdasarkan informasi dari "orang dalam" yang tidak publik sifatnya. Tindakan tersebut merugikan pihak lain yang tidak menerima informasi yang sama pada waktu yang sama, sehingga ia tidak dapat mengambil keputusan untuk membeli atau menjual saham yang dipegangnya.

Manipulasi Pasar, adalah praktek yang ditujukan pada distorsi terhadap kekuatan bebas atas persediaan dan permintaan. Pada umumnya, setiap manipulasi menggunakan restriksi artifisial pada "floacting supply of stock, "yang dikikuti oleh beberapa faktor untuk merangsang publik pada permintaan saham

\footnotetext{
${ }^{15}$ Ibid., him. 157.

${ }^{18}$ Suatu laporan berkala terdiri dari laporan tahunan dan laporan semester, yang berisi laporan neraca, laporan laba rugi, laporan saldo laba, laporan arus kas, catatan atas laporan keuangan dan lain-lain.
} 
dalam bentuk artifisial atau penciptaan penampilan palsu atas kegiatan perdagangan yang sebenarnya.

\section{Rahasia Bank yang GO Public}

Apabila suatu bank go public, maka bank tersebut akan terikat dengan tahap-tahap dan prosedur dalam proses Go Public tersebut. Artinya, bank dihadapkan pada kenyataan harus melaksanakan prinsip keterbukaan dalam mekanisme Pasar Modal.

Berdasarkan prinsip keterbukaan Bank harus memberikan segala informasi yang dibutuhkan bagi investor, namun di sisi lain Bank memiliki kewajiban untuk menjaga Rahasia Bank. Suatu hal yang sangat disayangkan sampai saat ini batasan yang jelas antara prinsip rahasia bank dengan full disclosure terhadap bank Go Public di pasar modal belum ada. ${ }^{17}$ Suatu batasan yang tegas berkenaan dengan prinsip rahasia bank dan full disclosure terhadap bank go public menjadi penting artinya mengingat ketentuan Undang-undang Perbankan Pasal 40 menuntut ditegakkannya bank secrecy principle, sedangkan di sisi lain full disclosure merupakan syarat fundamental prospektus pada saat melakukan initial public opering di pasar modal. ${ }^{18}$

Bank yang akan melakukan go public, akan membuat prospectus yang memuat kegiatan dan keuangan serta data keuangan. Bila bank yang melakukan go public tersebut menerapkan full disclosure terhadap data keuangan, dimana dalam data keuangan tersebut terdapat data pemberian kredit yang secara lengkap berisikan jumlah kredit dan nama krediturnya, hal ini berarti rahasia bank terhadap nasabah penerima kredit akan terungkap kepada publik, akibatnya bank melakukan pelanggaran terhadap rahasia bank.

Apabila prinsip rahasia bank harus tetap dipertahankan ketika berhadapan dengan prinsip full disclosure di pasar modarl berarti melegalisir bank yang tidak sehat dan pada gilirannya berarti menipu investor, selain itu bank tersebut secara tidak bertanggung jawab memperoleh fresh money. Sedangkan apabila rahasia bank dibuka maka anggota dewan komisaris, direksi, pegawai bank atau pihak terafiliasi lainnya yang sengaja memberikan keterangan yang wajib dirahasiakan dapat dikenakan ancaman penjara paling lama 2 (dua) Tahun dan denda paling banyak Rp. $2.000 .000 .000,00$ (dua milyar rupiah).

Kasus Bapindo dan Bank Duta dapat menjadi contoh terhadap tidak terbukanya bank dalam memberikan informasi berkenaan dengan kondisi keuangannya berkenaan dengan kredit-kredit yang diberikan kepada nasabahnya. Hasil audit Bapindo pada 1989, 1990, 1993 yang dilakukan Anderson - Utomo

${ }^{17}$ Pengaturan terhadap prinsip keterbukaan, sampai saat ini masih belum terperinci sehingga menimbulkan masalah-masalah penerapannya, Adapaun dampak belum terperincinya pengaturan terhadap prinsipketerbukaan (sampai dengan 2000) adalah banyaknya pelanggaran terhadap keterbukaan informasi di samping insider trading dan manipulasi pasar sehingga Bapepam telah mengenakan sanksi kepada 230 pihak. Lihat harian Kompas, 9 Februari 2001, him. 13.

10 Yahya Harahap, Beberapa Tinjauan tentang Permasalahan Hukum (Buku Kedua), (Bandung: Citra Aditya Bakti, 1997), him. 243 
\& Co, dinyatakan wajar (qualified). Dalam prospektus pada saat initial offering atas pengeluaran obligasi sebesar Rp. 600 milyar dikatakan tidak terlibat problem loan, malah dikatakan meraih keuntungan yang besar, yaitu 1986 keuntungan Rp. 105 milyar, 1990 keuntungan Rp. 142 milyar, 1991 keuntungan Rp. 161 milyar, 1992 keuntungan Rp: 177 milyar. Sedangkan 1993 dilaporkan aset Rp. 15 triliun dan hutang pada pihak ketiga Rp. 14,3 triliun. Padahal keadaan sebenarnya, sejak 1992 keuangan Bapindo dapat dikategorikan dalam keadaan bangkrut, karena modalnya hanya Rp. 600 milyar dan dibobol Eddy Tansil sebesar Rp. 1,7 triliun. Sedangkan dalam kasus bank Duta, sebelum go public 1991, sudah mengalami kerugian US $\$ 200$ juta, namun dalam prospektus dinyatakan tidak ada masalah. ${ }^{19}$

Tidak terbukanya kedua bank tersebut di atas dimungkinkan karena pada umumnya prospektus yang dibuat tidak mengandung nilai akurat yang tinggi, karena ini prospekktus tidak memberikan informasi yang bersifat siap pakai atau masih membutuhkan interpretasi $\mathrm{dn}$ analisis agar bisa menjadi informasi yang dapat dipakai, selain itu informasi tersebut bersifat kualitatif dan didasarkan pada taksiran belaka, sehingga pada akhirnya kondisi makro ekonomi jauh berbeda antara saat prospektus dibuat dengan kondisi sebenamya yang terjadi setelah go publik. ${ }^{20}$
Berkenaan dengan keterbukaan terhadap kondisi keuangan bank khususnya berkenaan dengan kriidit-kredit yang diberikan kepada nasabahnya tersebut, agar tidak bertentangan dengan prinsip rahasia bank dn memenuhi tuntutan full disclosure, maka harus dibedakan antara rahasia bank terhádap nasabah atau rahasia bank-secara umum atau rahasia korporat. Apabila rahasia bank tersebut - berkenaan dengan rahasia nasabah mana haruslah dilindungi dan tidak dapat dibuka kepada umum, sebab rahasia nasabah merupakan jiwa Perbankan. sedangkan apabila rahasia bank adalah berkenaan dengan masalah kondisi korporat atau perusahaan, misalnya apakah bank tersebut sehat atau tidak sehat maka hal tersebut merupakan rahasia bank yang bisa dibuka.

Krisna Wijaya memberikan pandangan yang senada berkenaan dengan keterbukaan rahasia bank, adapun pendapatnya adalah sebagai berikut: "Untuk bisa dilaksanakan keterbukaan mengenai apa yang terjadi di tubuh suatu bank, sebenarnya tidak ada kaitannya dengan rahasia bank. Sebab, yang akan diinformasikan adalah yang berkaitan dengan statusnya, yaitu apakah sehat, cukup sehat, kurang sehat dan tidak sehat. Ini tidak jauh beda seperti pengumuman mengenai peringatan suatu bank, baik yang dibuat oleh lembaga pemeringkat maupun majalahmajalah keuangan". ${ }^{21}$

${ }^{19} \mathrm{bid}$. , hlm. 244.

${ }^{20}$ Ary Suta, "Informasi dalam penawaran Umum", makalah disampaikan pada Pendidikan dan pelatihan bagi Profesi Penunjang Pasar Modal untuk Konsultasi Hukum Angkatan IV. Jakarta 10 Juli-22 Juli 1995. hlm. 8-9.

${ }^{21}$ Infobank. No. 219 Tahun 1997, him. 58. 
Tingkat kesehatan bank umum bisa dilihat dri dua sisi yaitu kualitatif dan kuantitatif. Dari sisi kualitatif dilihat dari pengelolaannya, sejarahnya, pemiliknya. Sisi kuantitatif dapat dilihat dari nilai tertentu seperti rasio likuiditas, solvabilitas, rentabilitas dan loar deposit ratio. Rasio likuiditas menunjukkan kemampuan bank dalam mengembalikan uang jangka pendek. Semakin tinggi nilai rasio likuiditās maka semakin baik pula kondisi kesehatan bank.22

Rasio solvabilitas menunjukkan kemampuan bank dalam mengembalikan uang jangka panjang. Semakin tinggi nilai rasio solvabilitas maka semakin baik kondisi kesehatan bank. Rasio profitabilitas menunjukkan kemampuan bank dalam menghasilkan laba. Capital Adequacy Ratio (CAR) dimaksudkan untuk mengukur kecukupan modal dengan membandingkan capita (modal) dengan aset berisiko. Loan Deposiit Ratio (LDR) digunakan untuk mengukur kemampuan bank dalam mengelola dana dengan membandingkan besarnya pinjaman yang diberikan oleh bank dengan besamya simpanan. ${ }^{23}$

Dengan demikian informasi emiten atau bank yang go public yang dapat di-ful disclosure adalah mengenai tingkat kesehatan bank dan kredit yang diberikan. Hal ini mutlak diumumkan untuk memberikan informasi atau data-data yang dapat mempengaruhi investor atu caion investor dalam mengambil keputusan pembelian efek.

\section{Simpulan}

Dari uraian di atas dapat disimpulkan bahwa hal-hal yang harus dirahasiakan pada saat bank go publik adalah masalah simpanan nasabah. Sedangkan yang harus di-disclosure adalah adalah masalah pemberian kredit baik dalam status lancar maupun macet serta tentang tingkat kesehatan bank.

Selain itu lebih memberikan kepastian, maka perlu pengaturan yang tegas guna memberikan batasan yang jelas antara prinsip rahasia bank dan prinsip ful disclosure dalam prospektus dan laporan berkala yang harus disampaikan ke Bapepam.

\section{Daftar Pustaka}

Djumhana, Muhammad, Hukum Perbankan di Indonesia, Bandung: Cutra Aditya Bakti, 1996.

Djumhana, Muhammad, Rahasia Bank (Ketentuan dan Penerapannya di Indonesia), Bandung: Citra Aditya Bakti, 1996.

Harahap, Yahya, Beberapa Tinjauan tentang Permasalahan Hukum Buku Kedua, Bandung: Cipta Aditya bakti, 1997.

Husein, Yunus, Rahasia bank Privasi Versus Kepentingan Umum, Jakarta: Program Pascasarjana Fakuitas Hukum Universitas Indonesia, 2003.

Nasution, Bismar, Keterbukaan dalam Pasar Modal, Jakarta: Fakultas Hukum Prohilm. 62.

${ }^{22}$ Subayo, Bank dan Lembaga Keuangan lainnya (Yogyakarta: Bagian Penerbitan STIE YKPN, 1997),

${ }^{23}$ ibid., him. 63. 
gram Pascasarjana Universitas Indo- Undang-undang No. 7 Tahun 1992 tentang nesia, 2001. Perbankan.

Subayo, Bank dan Lembaga Keuangan Linnya, Yogyakarta: Bagian Penerbitan STIE-YKNP, 1997.

Suta, Ary, "Informasi dalam Penawaran Umum," Makalah disampaiakn pada Pendidikan dan Pelatihan bagi Profesi penunjang Pasar Modal untuk Konsultan Hukum Angkatan IV. Jakarta 10 Juli - 22 Juli 1995.

Infobank, No. 219 Tahun 1997.

Harian Kompas. 9 Februari 2001.
Undang-undang No. 8 Tahun 1995 tentang Pasar Modal

Undang-undang No. 10 Tahun 1998 tentang Perubahan atas Undang-undang No. 7 Tahun 1992 tentang Perbankan

Peraturan pemerintah No. 45 Tahun 1945 tentang Penyelenggaraan Kegiatan di Bidang Pasar Modal.

Peraturan Bank Indonesia No. 3.22.PBI/2001 tentang Transparansi Kondisi keuangan.

208080 